\title{
Removal of Toxic Phenolic Compounds from Wastewater Using Zeolite (4A) Prepared from Local Clays Taken from the Slopes of the Tigris River
}

\author{
HUSSEIN A. ALABDLY ${ }^{1}$, INAS J. AL-NUAEMI ${ }^{2}$, \\ HUSSAM NADUM ABDALRAHEEM AL ANI ${ }^{2}$, SIMONA COTORCEA ${ }^{3}$, \\ AURELIA CRISTINA NECHIFOR ${ }^{3 *}$ \\ ${ }^{1}$ Al-Nahrain University, Department of Chemical Engineering, Baghdad-Iraq \\ ${ }^{2}$ Institute of Technology, The Middle Technical University, Baghdad- Iraq \\ ${ }^{3}$ Politehnica University of Bucharest, Department of Analytical Chemistry and Environmental Engineering,1-7 Gheorghe \\ Polizu Str., 011061, Bucharest, Romania
}

\begin{abstract}
The massive scale of industrial development has resulted in environmental pollution in general and water contamination in particular. It is important at the present time to treat water for the purpose of eliminating or reducing pollutants, especially toxic pollutants, such as phenol compounds. In this study, zeolite (4A) was prepared firstly from the available and cheap materials using an inclined rotary disk. Then, physical, mechanical, and chemical properties were also studied. Experiments were conducted to determine these properties using local clay and the following results were obtained: Zeolite (4A) $70 \%$ and clay $30 \%$, the time of calcination $3 \mathrm{~h}$ at a temperature of $850{ }^{\circ} \mathrm{C}$, breakage resistance of $17 \mathrm{Ib}$ pounds, surface area $530-590 \mathrm{~m}^{2} / \mathrm{g}$, grinding value $14 \%$ and moisture absorption ratio $30 \%$. The prepared zeolite (4A) was used in the process of removing phenolic compounds (chlorophenol, nitrophenol) by the adsorption method. Different amounts of prepared zeolite $(5 \mathrm{~g} / \mathrm{l}$ and $10 \mathrm{~g} / \mathrm{L})$ will be used in the treatment process and different concentrations $(2 \mathrm{mg} / \mathrm{L}, 5 \mathrm{mg} / \mathrm{L}$ and $10 \mathrm{mg} / \mathrm{L})$ of the pollutants Nitrophenol and Chlorophenol were used in the contaminated water tested. The removal process was carried out with a mixing speed of $200 \mathrm{rpm}$ and $\mathrm{pH}$ (7.5-8.5). From the results of this study, we note that the highest percentage of Nitrophenol removal is (84.8\%) when using an amount of zeolite (5g) and highest percentage of Nitrophenol removal is (95.5\%) when using an amount of zeolite (10g) while that the highest percentage of Chlorophenol removal is (78.3\%) when using an amount of zeolite (5g) and highest percentage of Chlorophenol removal is (0.894) when using an amount of zeolite (10g) it could be deduced that the percentage of the removal of nitrophenol was higher than that of chlorophenol because its solubility of chlorophenol in water is higher than the solubility of Nitrophenol.
\end{abstract}

Keywords: Adsorption, Chlorophenol, Nitrophenol, Wastewater and zeolite (4A)

\section{Introduction}

The research aims to manufacture zeolite from the available and cheap materials. The manufactured zeolite is used to treat water contaminated with toxic pollutants.

Chemical components such as nitrophenol and chlorophenol are considered the main source of industrial wastewater pollutants due to their toxicity and the difficulty of disposal of these contaminant materials [1-5].

There are many methods currently used to treat wastewater containing phenol compounds such as microbiological degradation, solvent extraction, chemical oxidation, filtration, ion-exchange, adsorption, precipitation, irradiation, incineration and biological treatment $[4,6]$. The adsorption process is considered one of the most effective techniques that are used to treat wastewater contaminated with organic pollutants [7]. Different types of Zeolite have been successfully used to overcome water pollution problems and help to remove pollutants such as phenols, chlorophenols and methylene blue dye from wastewater [8].

\footnotetext{
*email: aureliacristinanechifor@gmail.co
} 
Clay minerals are crystalline granules that have the ability to gain and lose water and have a high ability to exchange ions without changing the structure of clay minerals, such as Zeolite [9]. Zeolite is a granule of aluminium silicate stone which is a group of chemical elements consisting mainly of silicate and aqueous aluminate of alkali metals. Scientists have studied 175 types of zeolite in the last ten years, of which about 40 species are found naturally. High-porosity zeolite is able to hold positive ions such as $\mathrm{Na}^{+}, \mathrm{K}^{+}, \mathrm{Ca}^{+2}, \mathrm{Mg}^{+2}$ and others by adsorption these ions in the pores of the zeolite structure [10].

In general, two types of zeolites were reported, Natural zeolites and Industrial zeolite. Natural zeolites are found in basalt stones and sediments, and they were formed through ancient times under the influence of hot mineral water and there are 40 types of natural zeolites that have been discovered, the majority of which were named according to the name of their discoverer [11]. Given the scarcity of natural zeolites, scientists focused their efforts on creating zeolites that have the same properties as natural zeolite. There are 150 types of synthetic zeolites, which are the most used in industry [11].

Due to the unique properties of zeolites (porosity, pore size, specific surface area, apparent density and grinding resistance), which classified them as environmentally friendly compounds, they play a pivotal role in many applications and processes. Zeolites are used in various fields such as industry, agriculture, environmental protection and even in medicine. In Agriculture, zeolite works to stabilise the resulting ammonia in the soil and enrich it with nitrogen, so it is used as a fertiliser for the soil. Additionally, because of the feature of zeolite, such as the ability to absorb and loss water that makes it absorbs the excess water from the soil to give it to the plant when it needs it, while in Industry Zeolite is used as a catalyst in the manufacture of detergents. In addition, both natural and synthetic zeolites are able to filter water and remove suspended materials and impurities such as those used during cleaning pool water [12].

In particular, two types of natural zeolites, the mixture type (bulk) and the reddish type, were used to remove contaminants from the treated biological wastewater $[13,14]$. Molecular sieves are generally considered a type of zeolite consisting mainly of alumina and silica at a rate of about $50 \%$ in addition to a binder (kaolin) [15].

The chemical composition of molecular sieves provides them with special characteristics in the adsorption processes, and they are used as dehydration agents for air, gases, and fumes in precision devices, chemical and petrochemical industrial applications to adsorb moisture and remove a percentage of unwanted matter [16].

Zeolites were chosen based on the molecular size of the material to be adsorbed. The most important zeolite type (4A) is used in gases and air drying operations, whereas type (5A) is used to isolate paraffin from other hydrocarbons. Sieves have many uses in adsorption of sulphur compounds, carbon monoxide, water vapour, and compounds [17]. The zeolite (4A) in particular gains its importance in many industrial fields due to its advantages such as:

1- High capacity for vapours adsorption.

2- Reducing the Activation Energy and hence increasing the reaction speed.

3- Low economic cost and long service life can be reactivated.

4- It has a high surface area and high porosity as well.

5- The stability of its physical and chemical properties during its storage period.

6- High selectivity for chemical reaction [18].

\section{Materials and methods}

\subsection{Zeolite (4A) preparation}

\subsubsection{Materials}

The following materials have been used in this research for the preparation of zeolite (4A):

Kaolin powder, zeolite, distilled water. 


\subsubsection{Method of preparation}

The kaolin powder was sifted in order to obtain a specific granular volume (less than $45 \mu \mathrm{m}$ ) after grinding it with a ball mill. Then, the resultant powder was added to the zeolite and mixed with distilled water to make a paste. Different ratios of kaolin, zeolite and distilled water were performed to find the optimum mixture. The next step was forming balls from the dough by inserting it into an inclined rotary disk. The balls were dried for one to two hours at $250^{\circ} \mathrm{C}$ and then transferred into a special oven for high temperature calcination $\left(450-950^{\circ} \mathrm{C}\right)$ for three hours. Prepared molecular sieves were examined for evaluation as moisture absorbents under conditions close to actual conditions.

\subsection{Waste water treatment}

\subsubsection{Materials}

The following materials have been used in this research for the treatment of waste water: Distilled water, Chlorophenol, Nitrophenol and Zeolite (4A)

\subsubsection{Method of treatment}

The zeolite (4A) prepared above was used for wastewater treatment in this experiment. Different quantities of zeolite (4A), $5 \mathrm{~g}$ and $10 \mathrm{~g}$, were mixed with three samples of prepared water $(1 \mathrm{~L})$. Each sample of water contained a different concentration of Nitrophenol: $2,5,10 \mathrm{mg} / \mathrm{L}$. The Processed water was mixed with zeolite using 6 flasks under these conditions: Fixed temperature at $25^{\circ} \mathrm{C}, p \mathrm{H} 7.5$ and agitation speed $200 \mathrm{rpm}$. After that, the samples were collected and the concentrations of Nitrophenol in the water were examined at different periods of time $(0-120) \mathrm{min}$. The same procedure was performed by adding 2,5,10 $\mathrm{mg} / \mathrm{L}$ of Chlorophenol to the distilled water instead of Nitrophenol. This experiment was also carried out at $25^{\circ} \mathrm{C}$ and $200 \mathrm{rpm}$ but the $p \mathrm{H}$ was 8-8.5.

\section{Results and discussions}

\subsection{Characterization of zeolite $(4 \mathrm{~A})$ prepared}

From the results, it was observed that when the composition of zeolites was increased from 50 to $95 \%$, both the grinding resistance and the absorbance increase up to a certain percentage and then the rate of increasing started to slow down. Stability in grinding resistance and the absorbance could be due to a decrease in the surface area and the absorption efficiency. These results are represented clearly in Table 1, Figure 1 and Figure 2. In Figure 1 the relationship between the ratio of added zeolites and grinding resistance are shown. It can be seen that initially the increase in grinding resistance was very high, and then at high levels of zeolites it became very low because the infrastructure of sieves will become weak and fragile.

Figure 2 represents the relationship between the percentage of added zeolites and the absorption ratio. It could be observed that at the beginning the absorption rate increased until the added zeolite ratio reached about $85 \%$, after which the absorption ratio is approximately fixed because the infrastructure of sieves is saturated with zeolite and has less clay [19].

Table 1. Effect of zeolite and kaolin ratio on milling and absorbance value

\begin{tabular}{|c|c|c|c|}
\hline Zeolite $\%$ & Kaolin \% & $\begin{array}{c}\text { Crushing value\% } \\
\text { (C.V \%) }\end{array}$ & Absorptivity \% \\
\hline 50 & 50 & 4 & 9.3 \\
\hline 55 & 45 & 5.31 & 12.2 \\
\hline 60 & 40 & 7.23 & 13.5 \\
\hline 65 & 35 & 8.92 & 15.6 \\
\hline 70 & 30 & 10.56 & 20.5 \\
\hline 75 & 25 & 13.3 & 20.7 \\
\hline 80 & 20 & 13.6 & 20.8 \\
\hline 85 & 15 & 13.7 & 21.0 \\
\hline 90 & 10 & 13.9 & 21.2 \\
\hline 95 & 5 & 14.00 & \\
\hline
\end{tabular}




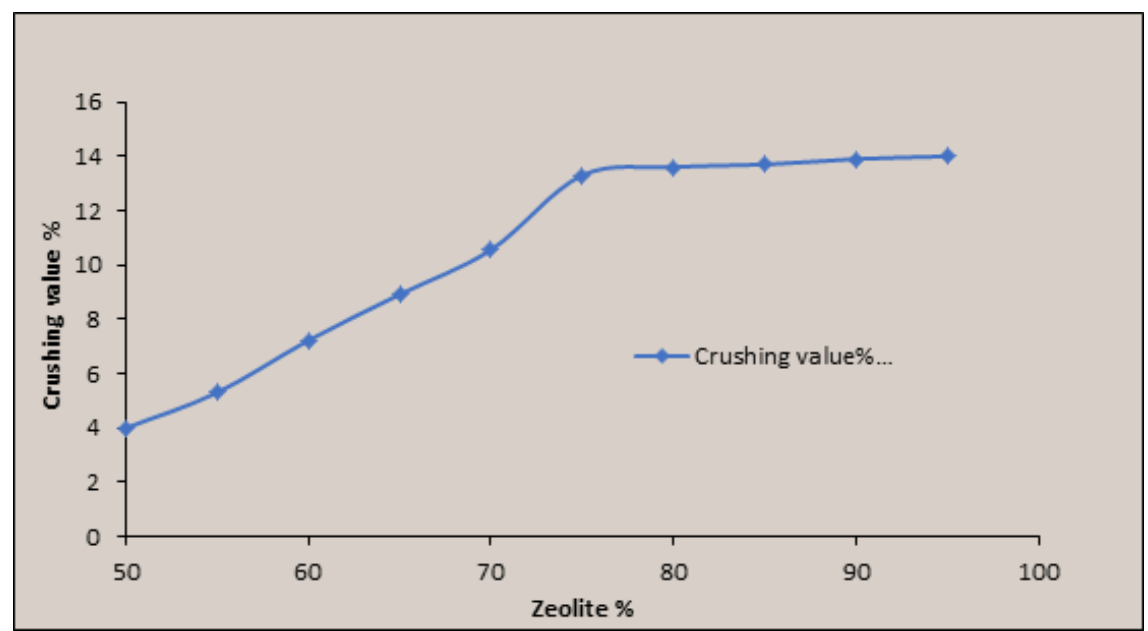

Figure 1. Relation between \% zeolite with crushing value\% (C.V)

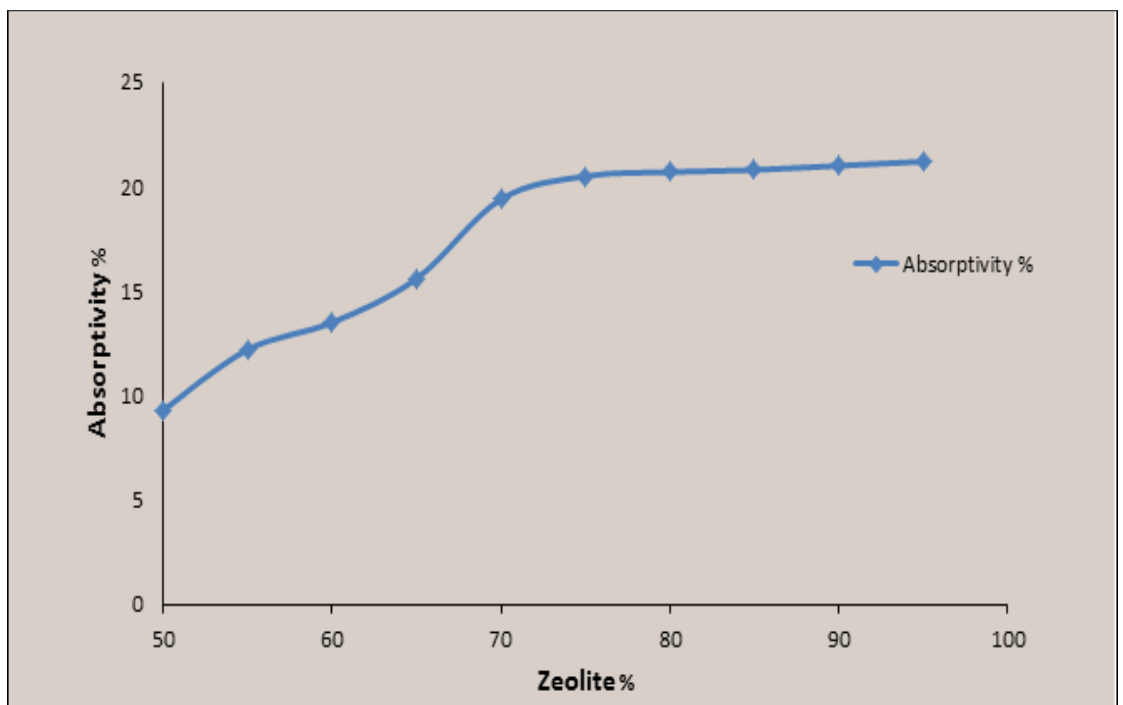

Figure 2. Relation between the \% zeolite with \% absorptivity

The temperature of calcination was evaluated for a range between $550-1000^{\circ} \mathrm{C}$. It was noted that the grinding value decreased with rising temperatures to a limit of $800^{\circ} \mathrm{C}$, and then it started to increase. Therefore, it could indicate that the optimum temperature would be $850^{\circ} \mathrm{C}$. Table 2 and Figure 3 show the relationship between the temperature of calcination and the value of grinding.

Table 2. Effect of calcination temperature on milling value

\begin{tabular}{|c|c|}
\hline Calcination Temperature ${ }^{\circ} \mathrm{C}$ & Crushing Value \% (C.V) \\
\hline 550 & 18.3 \\
\hline 600 & 16.5 \\
\hline 650 & 15.9 \\
\hline 700 & 14.8 \\
\hline 750 & 14.2 \\
\hline 800 & 13.5 \\
\hline 850 & 15.4 \\
\hline 900 & 15.2 \\
\hline 950 & 16.3 \\
\hline 1000 & 17.6 \\
\hline
\end{tabular}




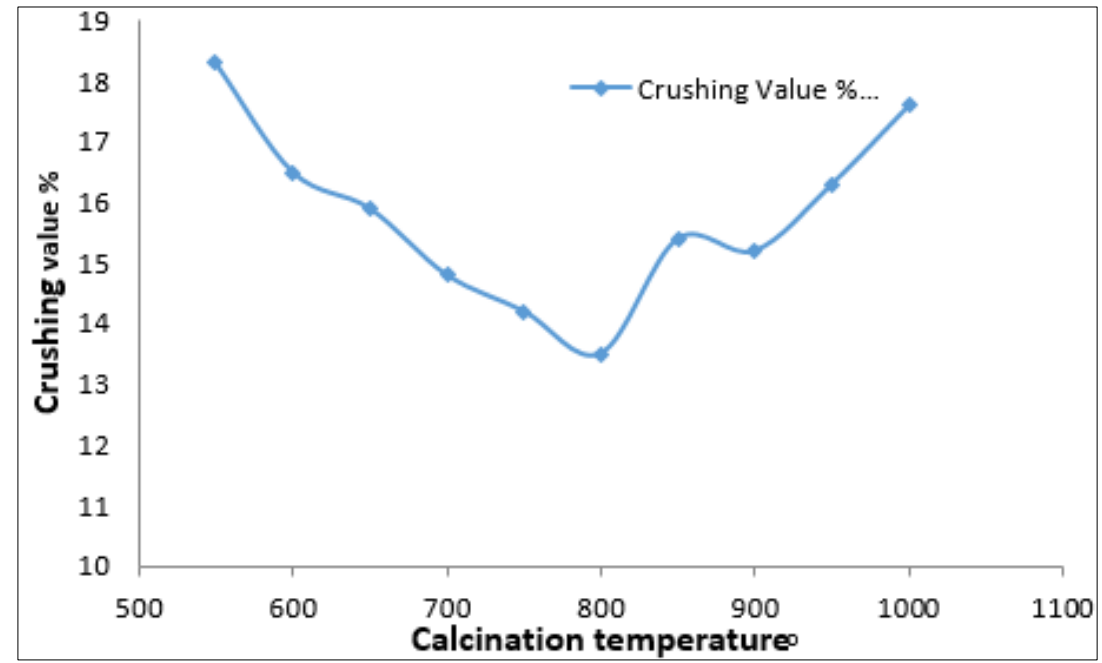

Figure 3. Relation between calcinations temperature and crushing value

Grinding value was also investigated and it was found that it increased with the increase of calcination time until three hours, and then it was fixed. This finding indicates that the optimum calcination time is about $3 \mathrm{~h}$. Table 3 and Figure 4, which clarify the relationship between the calcination time and the grinding value, showed that the grinding value was established after about three hours of the calcination time.

Table 3. The effect of calcination time on the value of grinding

\begin{tabular}{|c|c|}
\hline Calcination time (hr) & Crushing value (C.V \%) \\
\hline 1 & 12.2 \\
\hline 2 & 12.8 \\
\hline 3 & 13.4 \\
\hline 4 & 14.4 \\
\hline 5 & 15.7 \\
\hline 6 & 16.8 \\
\hline 7 & 16.9 \\
\hline
\end{tabular}

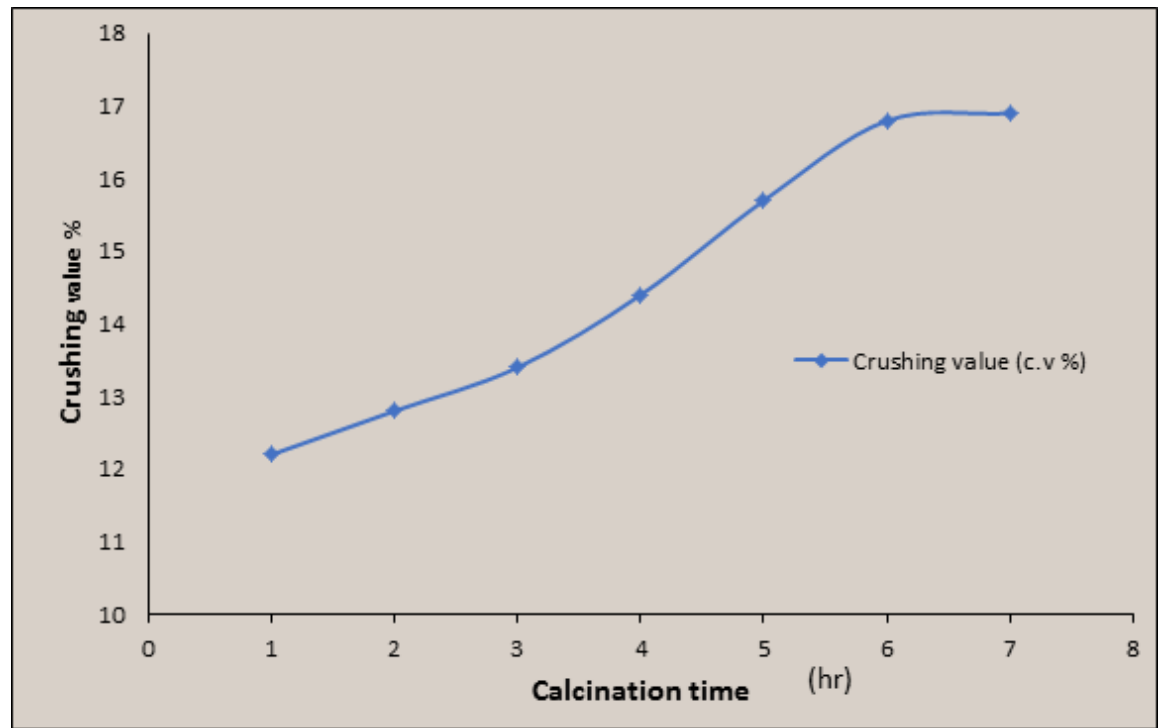

Figure 4. Relation between the calcinations time and \% crushing value

From observing Tables (1-3) and Figures (1-4) and analysing the results, the specifications of the prepared partial sieves can be summarised in Table 4 as follows: 
Table 4. Specifications of prepared sieves

\begin{tabular}{|c|c|c|}
\hline No. & Prosperity & Value \\
\hline 1 & Specific Surface Area & $570 \mathrm{~m}^{2} / \mathrm{g}$ \\
\hline 2 & Bulk density & $630 \mathrm{~kg} / \mathrm{m}^{3}$ \\
\hline 3 & Moisture absorption ratio & $\% 30$ \\
\hline 4 & Milling value & $14 \%$ \\
\hline 5 & Calcination temperature & $850^{\circ} \mathrm{C}$ \\
\hline 6 & Calcination time & $3 \mathrm{hrs}$. \\
\hline 7 & Brealkage resistance & $7.718 \mathrm{~kg}$ \\
\hline
\end{tabular}

\subsection{Water treatment}

Before discussing the results that have been recorded during the treatment of water that polluted with Nitrophenol and Chlorophenol, it is essential to identify some of the physical properties of those pollutants (Table 5).

Table 5. Some characteristics of Nitrophenol and Chlorophenol [20-23]

\begin{tabular}{|c|c|c|c|}
\hline No. & Prosperity & Nitrophenol & Chlorophenol \\
\hline 1 & Chemical formula & $\mathrm{C}_{6} \mathrm{H}_{5} \mathrm{NO}_{3}$ & $\mathrm{C}_{6} \mathrm{H}_{5} \mathrm{ClO}$ \\
\hline 2 & Formula weight $(\mathrm{g} / \mathrm{ml})$ & 139.11 & 128.55 \\
\hline 3 & Boiling point $\left({ }^{\circ} \mathrm{C}\right)$ & $279{ }^{\circ} \mathrm{C}$ & $175{ }^{\circ} \mathrm{C}$ \\
\hline 4 & Specific gravity $\left(\right.$ at $\left.20{ }^{\circ} \mathrm{C}\right)$ & 1.47 & 1.265 \\
\hline 5 & Solubility in water at $25{ }^{\circ} \mathrm{C}(\mathrm{g} / 100 \mathrm{ml})$ & 1.16 & 2.7 \\
\hline
\end{tabular}

First, we will calculate the adsorption efficiency $(\% \mathrm{R})$ by the following relationship for each concentration (1):

where:

$$
\% \mathbf{R}=\left(\mathrm{c}_{\mathrm{o}}-\mathrm{c}_{\mathrm{f}}\right) / \mathrm{c}_{\mathrm{o}} \times 100 \%
$$

$\mathrm{c}_{\mathrm{f}}$ - the final concentration of the solute (nitrophenols or Chlorophenol)

$\mathrm{c}_{\mathrm{o}}$ - the initial concentration of solute (nitrophenols or Chlorophenol)

Figure 5 clarifies the relation between $(\% \mathrm{R})$ for Nitrophenol at different concentration $(2,5$, and 10$)$ $\mathrm{mg} / \mathrm{L}$ with time at the flowing conditions: the agitation speed was $200 \mathrm{rpm}, p \mathrm{H}$ equal 7.5 and the temperature was $25^{\circ} \mathrm{C}$. The amount of adsorbent (zeolite $4 \mathrm{~A}$ ) that used for this experiment was $5 \mathrm{~g}$. In Figure 6 the same relation between $(\% \mathrm{R})$ for Nitrophenol at different concentration $(2,5$, and 10$) \mathrm{mg} / \mathrm{L}$ with time was represented but the amount of zeolite (4A) was doubled to be $10 \mathrm{~g}$ instead of $5 \mathrm{~g}$.

It could be noticed from Figures 5 and 6 that the highest rate of Nitrophenol removal was $84.8 \%$ when $10 \mathrm{mg} / \mathrm{L}$ of Nitrophenol was added to the water. This rate was recorded when $5 \mathrm{~g}$ of zeolite was used while the rate of removed Nitrophenol increased to $95.9 \%$ when $10 \mathrm{~g}$ of zeolite was applied. This result could be very well due to the increase of surface area as a result of increasing the quantity of the adsorbed substance which could lead to a higher removal rate [24, 25]. Additionally, the lowest removal rate of nitrophenol (79\%) was also established when a quantity of $5 \mathrm{~g}$ of zeolite and $2 \mathrm{mg} / \mathrm{L}$ of nitrophenol were used.

Figure 7 shows the relation between $(\% \mathrm{R})$ for Chlorophenol at different concentration $(2,5$, and 10$)$ $\mathrm{mg} / \mathrm{L}$ with time at the flowing conditions: the agitation speed was $200 \mathrm{rpm}, p \mathrm{H}$ equal 8 , the temperature was $25^{\circ} \mathrm{C}$ and $5 \mathrm{~g}$ of adsorbent (zeolite $4 \mathrm{~A}$ ). While Figure 8 clarifies the relationship between (\%R) for Chlorophenol at different concentration $(2,5$, and 10$) \mathrm{mg} / \mathrm{L}$ with time at the flowing conditions: the agitation speed was $200 \mathrm{rpm}, p \mathrm{H}$ equal 8.5 and the temperature was $25^{\circ} \mathrm{C}$. This experiment was performed by using $10 \mathrm{~g}$ of zeolite $4 \mathrm{~A}$.

The effect of using different concentrations of zeolite on chlorophenol is evident from Figures 7 and 8. It can be observed that the highest percentage of chlorophenol removal was $87.3 \%$ when $5 \mathrm{~g}$ of zeolite and $10 \mathrm{mg} / \mathrm{L}$ of chlorophenol were used. It was noticed that the ratio of removal increased to $89.4 \%$ when $10 \mathrm{~g}$ of zeolites at the same concentration of chlorophenol was used. On the other hand, the lowest 
treatment percentage for Chlorophenol removal which was $(70.9 \%)$ was established when $5 \mathrm{~g}$ of zeolite and $2 \mathrm{mg} / \mathrm{L}$ of Chlorophenol were used [26, 27].
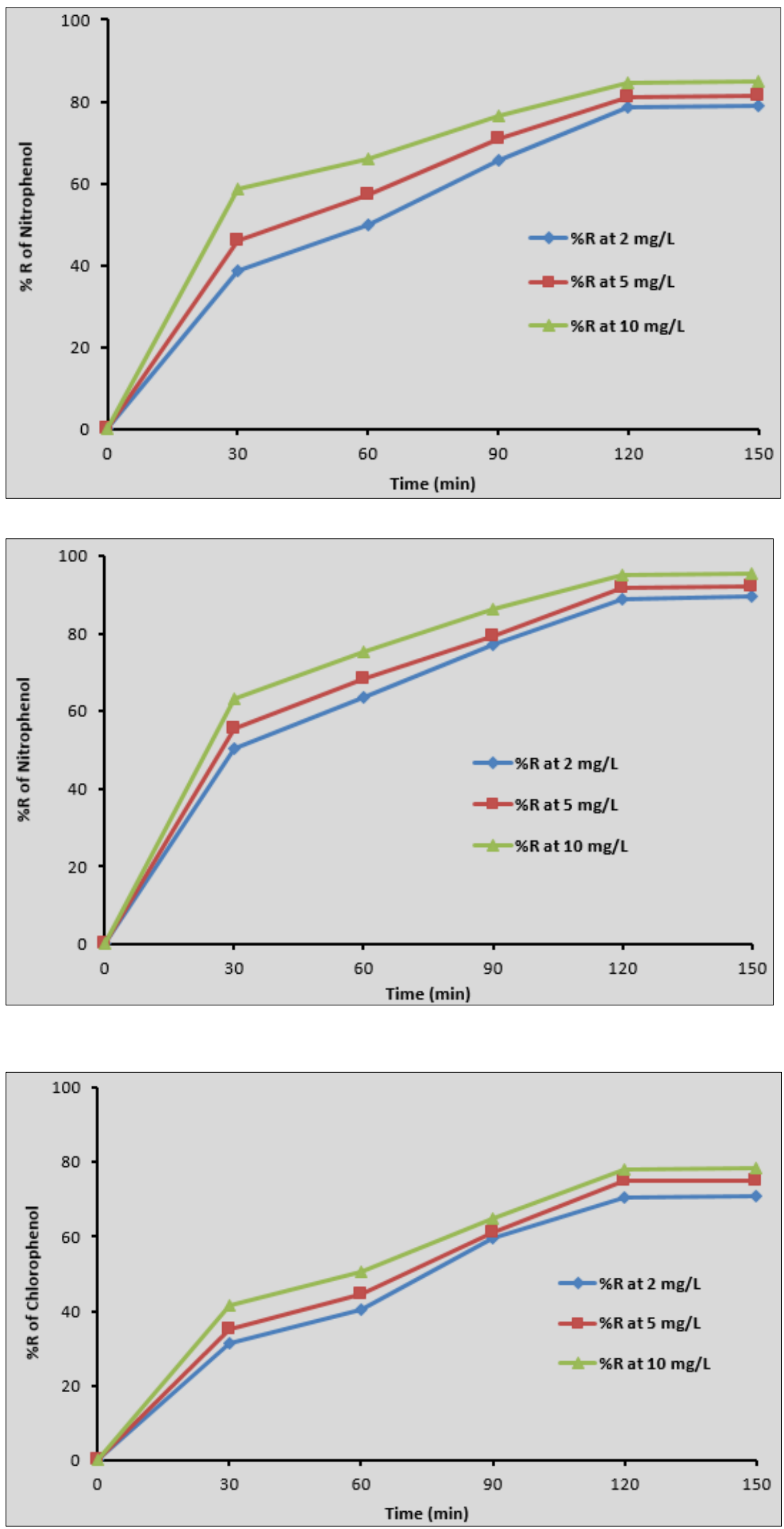

Figure 5. The relation between adsorption efficiency $(\% \mathrm{R})$ for

Nitrophenol at different concentration with time at adsorbent $5 \mathrm{~g}$
Figure 6. The relation between adsorption efficiency $(\% \mathrm{R})$ for

Nitrophenol at different concentration with time at adsorbent $10 \mathrm{~g}$
Figure 7. The relation between adsorption efficiency (\%R) for Chlorophenol at different concentration with time at adsorbent $5 \mathrm{~g}$ 


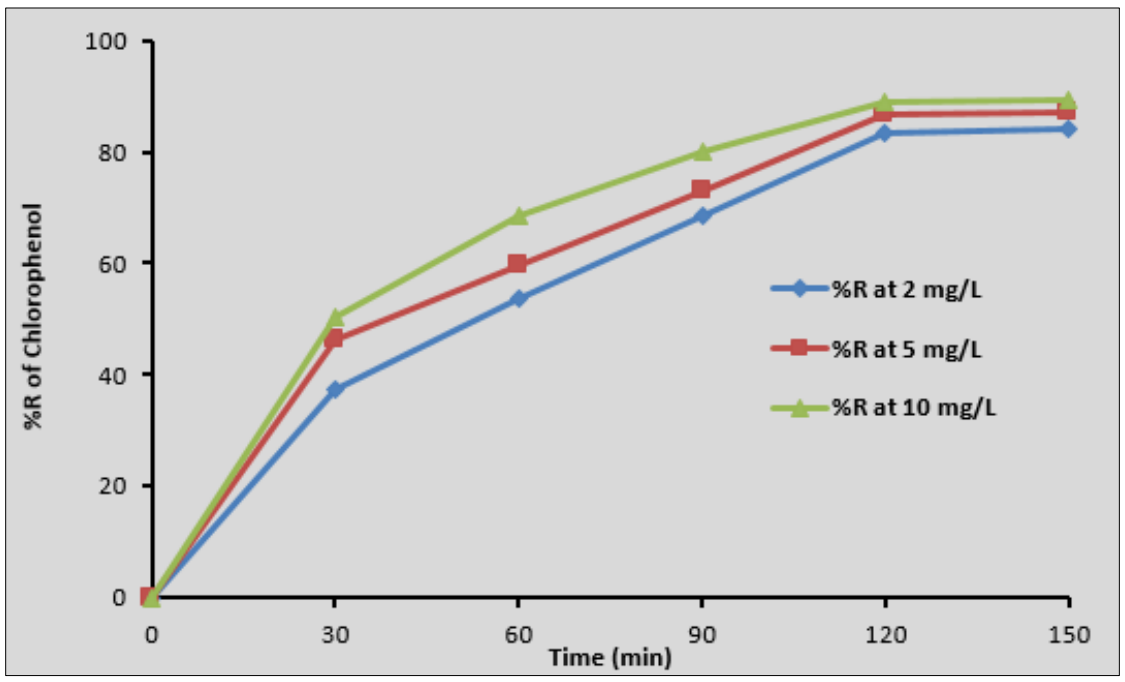

Figure 8. The relation between adsorption efficiency $(\% \mathrm{R})$ for Chlorophenol at different concentration with time at adsorbent $10 \mathrm{~g}$

\section{Conclusions}

The zeolite was prepared using the appropriate technology for manufacturing this type using inclined Rotary Disk where the basic components of the catalyst and its proportions were identified. The catalyst that was produced from this project was obtained from local materials at low cost taking into consideration the high cost of other catalyst used in different industries in general, and in oil industries specifically. The prepared molecular sieves showed the possibility of reuse after cleaning and purifying them. It could be evidenced that the specifications of the manufactured sieves are close to the imported ones in terms of efficiency.

From the results, it could be evidence that the zeolite that was prepared from local materials can be used for removing toxic organic substances present in water, especially phenol compounds such as Nitrophenol and Chlorophenol. Additionally, the results from this project proved that the ability of zeolite to remove the Nitrophenol from water is higher than its ability to treat the Chlorophenol at the same conditions. This may due to the differences in physical properties of these two materials as water treatment depends on the solubility. As a result the separation of Chlorophenol is more difficult because its solubility in water is higher than the solubility of Nitrophenol.

Acknowledgement: The PhD student Simona COTORCEA work has been funded by the Operational Programme Human Capital of the Ministry of European Fundst hrough the Financial greement 51668/09.07.2019, SMIS code 124705 (SIMBA project).

\section{References}

1. NAFLIU, I. M., AL ANI, H. N. A., GROSU (MIRON), A. R., TANCZOS, S.K., MAIOR, I., NECHIFOR, A. C., Iono-molecular Separation with Composite Membranes, Mater. Plast., 55(4), 2018, 511.

2. RANA, A. A., AHLAM, A. F., HUSSAM, N. A. AL ANI, NECHIFOR, A. C., Determination of the Optimal Condition

of Direct Blue Dye Removal from Aqueous Solution Using Eggshell, Rev. Chim, 70(4), 2019, 1108.

3. ARDELEAN, R., DAVIDESCU, C.M., POPA, A., Chem. Bull. "Politehnica" Univ. Timisoara, 55, no. 69,2010, p. 132 .

4. MOYO, M., MUTARE, E., CHIGONDO, F., NYAMUNDA, B. C., Removal of phenol from aqueous solution by adsorption on yeast, saccharomyces cerevisiae, IJRRAS, 11(3), 2012, p. 486. 
5. DIN, I. S., CIMBRU, A. M., AL ANI, H. N. A., NAFLIU, I. M., TANCZOS, S.K., NECHIFOR G., Iono-molecular Separation with Composite Membranes V. Nitro-phenol separation on n-alkyl alcohols supported liquid membranes, Rev. Chim., 69(5), 2018, 1084.

6. DENILZI, A., CIHANGER, N., TUZMEN, N., ALSANCAK, G., Bioresour. Technol., 96, 1), 2005, p.59.

7. CRINI, G. Recent Developments in Polysaccharide Based Materials Used as Adsorbents in Waste Water Treatment, Prog. Polym. Sci., 2005, p. 38.

8.OKOLO, B., PARK, C., KEANE, M. A., J. Colloid Interface Sci., 226, 2000, p.308.

9. BUSH, M. AL., Clay Minerals, Arab Gelogen Union, 2016.

10. BRECK, D. W., Zeolite Molecular Sieves, Wiley - Inter Science, 1974.

11. COLELLA, C., Natural zeolites, Studies in surface science and catalysis, 157, 2005, p.13.

12. BACKHURST, J.R., J. H. HARKER, Chemical Engineering, Vol. Five, Pergamon Press, 2006.

13. KALLO, D., Applications of Natural Zeolites in Water and Wastewater Treatment, Reviews in mineralogy and geochemistry, 45, no.1, 2001, p. 519.

14. MONTALVO, S., GUERRERO, L., BORJA, R., Application of natural zeolites in anaerobic digestion processes, Applied Clay Science, 58, 2012, p.125.

15. GRACE, W.R., Co. Enriching lives, Everywhere-Zeolite structure-Grace. com., 2010.

16. DAVID, E., ARMEANA, A., LAZAR, A., Characterization of some materials with porous structure, $11^{\text {th }}$ International Scientific Conference-Achievements in Mechanical and Materials Sciences, Polish Academy of Science, 2002, p. 71.

17. SHERMAN, J. D., Synthetic zeolites and other microporous oxide molecular sieves, Proceedings of the National Academy of the United States of America, 96(7), 1999, p.3471.

18.www.Zeolite(natural) USGS mineral commodity summaries 2011.

19. DRZAJ, B., HO CEVOR, S., PEJENIK S., Synthesis, Structure, Technology and Application, Elsevier Science, Volume $24,1985$.

20. O'NEIL, M.J. (ed.), the Merck Index - An Encyclopedia of Chemicals, Drugs, and Biologicals. Whitehouse Station, NJ: Merck and Co., Inc., 2006, p. 1145.

21.LEWIS, R.J. SR., John Wiley \& Sons, Inc. New York, NY, 2007, p. 3.

22. LIDE, D.R., Milne, G.W.A., (eds.), 3rd ed. CRC Press, Inc. Boca Raton, Volume I., 1994, p. V4: 401.

23. LIDE, D.R., 2005, CRC Handbook 86TH Edition 2005-2006., CRC Press, Taylor \& Francis, Boca Raton, p.3.

24. PATNAIK, P., KHOURY, J.N., Reaction of phenol with nitrite ion: Pathways of formation of nitrophenols in environmental waters, Water Research, 38, no. 5, 2004, p.206.

25. KARIM, K., GUPTA, S.K., Continuous biotransformation and removal of nitrophenols under denitrifying conditions, Water Research, 37, no.12, 2003, p.2953.

26. LEWIS, R.J., Sax's Dangerous Properties of Industrial Materials. 10th ed. Volumes 1-3 New York, NY: John Wiley \& Sons Inc., Volume 2, 1999, p. 27.

27. LEWIS, R.J. SR., John Wiley \& Sons, Inc. New York, NY, 2001, p. 257.

Manuscript received: 28.06 .2020 